American Journal of Biochemistry and Biotechnology 5 (4): 170-179, 2009

ISSN 1553-3468

(C) 2009 Science Publications

\title{
Characterization of Pullulanase Type II from Bacillus cereus H1.5
}

\author{
${ }^{1}$ Hii Siew Ling, ${ }^{2}$ Tau Chuan Ling, ${ }^{1,3}$ Rosfarizan Mohamad and ${ }^{1,3}$ Arbakariya B. Ariff \\ ${ }^{1}$ Laboratory of Industrial Biotechnology, Institute of Bioscience, \\ University Putra Malaysia, 43400 UPM Serdang, Selangor, Malaysia \\ ${ }^{2}$ Department of Food and Process Engineering, Faculty of Engineering, \\ University Putra Malaysia, 43400 UPM Serdang, Selangor, Malaysia \\ ${ }^{3}$ Department of Bioprocess Technology, Faculty of Biotechnology and Biomolecular Sciences, \\ University Putra Malaysia, 43400 UPM Serdang, Selangor, Malaysia
}

\begin{abstract}
Problem statement: Pullulanase is one of the important enzymes in starch industry. Search for the pullulanase with distinct features, possibly from easily grown bacterium, is of interest for industrial applications Approach: The extracellular pullulanase produced by Bacillus cereus HI.5 was purified by chromatographic method of DEAE-Sepharose, followed by Superdex gel filtration. The enzyme was characterized in terms of the optimal $\mathrm{pH}$ and temperature for activity as well as substrate specificity. Results: The enzyme showed optimal activity at $55^{\circ} \mathrm{C}$ and $\mathrm{pH}$ 6.0. The thermostability and the thermoactivity of the enzyme were increased considerably in the presence of $\mathrm{Ca}^{2+}$. In the present of $2 \mathrm{mM} \mathrm{Ca}^{2+}$, the enzyme had half-life duration of more than $2 \mathrm{~h}$ at $50^{\circ} \mathrm{C}$. Almost all metal ions had a strong inhibitory effect, except $\mathrm{Ca}^{2+}$ and $\mathrm{Mn}^{2+}$. The $\mathrm{Ca}^{2+}$ had a very strong stimulating effect on the enzyme, increasing its activity by $170 \%$. The enzyme was activated by 2 -mercaptoethanol and dithiothreitol, where as N-bromosuccinimide and Schardinger dextrins were inhibitors, suggesting that tryptophan and thiol residues may be important for the activity. The apparent $K_{m}$ and $V_{\max }$ value for pullulan was $1.1 \mathrm{mg} \mathrm{mL}^{-1}$ and $0.275 \mu \mathrm{mol} \mathrm{min} \mathrm{m}^{-1}$, respectively. A relative substrate specificity for hydrolysis of pullulan, amylopectin and soluble starch by this pullulanase was $100 \%, 28.5 \%$ and $20.4 \%$, respectively. Conclusion: The enzyme was able to attack specifically the $\alpha-1,6$ linkages in pullulan to generate maltotriose as the major end product, as well as the $\alpha-1,4$ linkages in amylopectin and soluble starch leading to the formation of a mixture of maltose and glucose and therefore be classified as a type II pullulanase or an amylopullulanase.
\end{abstract}

Key words: Pullulanase, amylopullulanase, Bacillus cereus, starch, substrate specificity

\section{INTRODUCTION}

Pullulan is a linear glucan of maltotriosyl units (Glc $\alpha 1-4 \mathrm{Glc} \alpha 1-4 \mathrm{Glc}$ ) linked through $\alpha-1,6$ glucosidic linkages. The $\alpha-1,6$ linkages are considered partially to mimic the $\alpha-1,6$ branch points of amylopectin and pullulan has been widely employed as a model substrate for starch-debranching enzymes ${ }^{[1]}$. Enzymes that hydrolyze pullulan have been classified into five groups based on the substrate specificity and end product ${ }^{[2,3]}$. They are: (i) pullulan hydrolase type I (neopullulanase, EC 3.2.1.135) which hydrolyzed $\alpha-1,4$ glycosidic linkage of pullulan to form panose; (ii) pullulan hydrolase type II (isopullulanase, EC 3.2.1.57) which acts on pullulan to form isopanose; (iii) pullulan hydrolase type III which attacks $\alpha-1,4$ as well as $\alpha-1,6$ glycosidic linkages in pullulan forming a mixture of maltotriose, panose and maltose; (iv) pullulanase type I (EC 3.2.1.41) specifically hydrolyses $\alpha-1,6$ glycosidic linkages in pullulan or branched substrates such as amylopectin forming maltotriose and (v) pullulanase type II (amylopullulanase) attacks $\alpha-1,6$ linkages in pullulan and branched substrates in addition to $\alpha-1,4$ links in polysaccharides other than pullulan ${ }^{[2,4]}$.

Among pullulanase type II, amylopullulanases are interesting in starch processing industry due to the specific debranching capacity of hydrolyzing either $\alpha-1,6$ and $\alpha-1,4$ glycosidic linkages. A number of pullulanase with dual specificities have been investigated, including pullulanase from Bacillus subtilis ${ }^{[5]}$,

Corresponding Author: Arbakariya B. Ariff, Department of Bioprocess Technology,

Faculty of Biotechnology and Biomolecular Sciences, University Putra Malaysia, 43400 UPM Serdang, Selangor, Malaysia Tel: 60389467591 Fax: 60389467510 
Thermoanaerobium $\quad$ brockii $^{[6]}, \quad$ Clostridium thermohydrosulfuricum ${ }^{[7,8]}$, Bacillus circulans $^{[9]}$, Bacillus sp. ${ }^{[10]}$, Clostridium thermosulfurogenes ${ }^{[11]}$, Thermus aquaticus ${ }^{[12]}$, Thermoanaerobacterium saccharolyticum $^{[13]}$, Pyrococcus furiosus and Thermococcus litoralis $^{[14]}$, an alkalophilic Bacillus sp. ${ }^{[15]}$ and Bacillus sp. ${ }^{[3]}$.

In this study, pullulanase produced by Bacillus cereus HI.5, isolated from Malaysian soil, was purified and characterized. In addition, substrate specificity and the hydrolysis products were also analyzed.

\section{MATERIALS AND METHODS}

Microorganism: Bacillus cereus $\mathrm{H} 1.5$, obtained from a culture collection unit at the Laboratory of Industrial Biotechnology, Institute of Bioscience, Universiti Putra Malaysia, was used in this study. This pullulanase producing strain was isolated from soil using red pullulan agar method.

Production of pullulanase: The $B$. cereus $\mathrm{H} 1.5$ culture was initiated in $1 \mathrm{~L}$ shake flasks. The culture medium consisted of (w/v) $1 \%$ gelatinized sago starch, $0.5 \%$ yeast extract, $0.03 \% \quad \mathrm{~K}_{2} \mathrm{HPO}_{4}, \quad 0.02 \%$ $\mathrm{MgSO}_{4} .7 \mathrm{H}_{2} \mathrm{O}, 0.1 \%\left(\mathrm{NH}_{4}\right)_{2} \mathrm{SO}_{4}, 0.02 \% \mathrm{CaCl}_{2} .2 \mathrm{H}_{2} \mathrm{O}$, $0.001 \% \mathrm{FeSO}_{4} .7 \mathrm{H}_{2} \mathrm{O}$ and $0.0001 \% \mathrm{MnCl}_{2} \cdot 4 \mathrm{H}_{2} \mathrm{O}$. The $\mathrm{pH}$ of all media was adjusted to 5.5 with $1 \mathrm{M} \mathrm{HCl}$ prior to sterilization at $121^{\circ} \mathrm{C}$ for $20 \mathrm{~min}$. After incubation of the cultures at $30^{\circ} \mathrm{C}$ for $24 \mathrm{~h}$, the cells were removed from the culture medium by centrifugation at 10,000 rpm for $15 \mathrm{~min}$.

The supernatant was used for further purification. The supernatant was treated with $\left(\mathrm{NH}_{4}\right)_{2} \mathrm{SO}_{4}$ at $80 \%$ saturation and the flask was continuously stirred for overnight precipitation. The precipitate formed was collected by centrifugation at 20,000 rpm for $5 \mathrm{~min}$ and the pellets were suspended and dissolved in $0.02 \mathrm{M}$ sodium phosphate buffer, $\mathrm{pH} 6.9$ and dialyzed against the same buffer for $24 \mathrm{~h}$ at $4^{\circ} \mathrm{C}$ with two buffer changes.

Enzyme purification: All chromatographic steps were performed at $4^{\circ} \mathrm{C}$ using Akta Prime system (Pharmacia Amersham Biotech, Sweden). The dialyzed enzyme preparation was applied to a DEAE-Sepharose C1 6B FF column $(2.5 \times 30 \mathrm{~cm})$ with $0.02 \mathrm{M}$ sodium phosphate buffer, pH 6.9. The column was washed with the same buffer and bound proteins were eluted by applying a linear gradient of $0-1.0 \mathrm{M} \mathrm{NaCl}$ in the same buffer at a

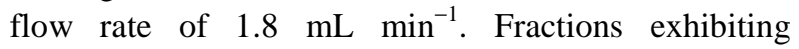
pullulanase activity were pooled and concentrated by freeze-drying. Samples were dissolved in a minimal volume of $0.02 \mathrm{M}$ sodium phosphate buffer, $\mathrm{pH}$ 6.9. and dialyzed against the same buffer for $24 \mathrm{~h}$ at $0.02 \mathrm{M}$ sodium phosphate buffer, $\mathrm{pH} 6.9$ and $4^{\circ} \mathrm{C}$, with two buffer changes.

For further purification of the enzyme, gel filtration was performed onto a Superdex 75 (10/300 GL) gel filtration column $(1.0 \times 30 \mathrm{~cm})$, equilibrated with $0.02 \mathrm{M}$ sodium phosphate buffer, $\mathrm{pH}$ 6.9. Elution at a flow rate of $0.5 \mathrm{~mL} \mathrm{~min}{ }^{-1}$ was performed using the same buffer. The active fraction pooled and concentrated by ultrafiltration was used as the purified enzyme for further analysis. The purity and molecular mass of the enzyme were determined using SDS-PAGE, using BioRad Mini protean II apparatus at $100 \mathrm{~V}$. Protein standards were co-migrated and stained with silver staining kid (Amersham Biosciences).

Assay of pullulanase activity: Enzyme activity was determined by measuring the enzymatic release of reducing sugar from pullulan ${ }^{[16]}$. In this assay, $0.5 \mathrm{~mL}$ of enzyme sample was added into $0.5 \mathrm{~mL}$ of $1 \%(\mathrm{w} / \mathrm{v})$ pullulan in $0.02 \mathrm{M}$ sodium phosphate buffer, $\mathrm{pH}$ 6.9. The reaction mixture was incubated at $40^{\circ} \mathrm{C}$ for $30 \mathrm{~min}$ and the amount of reducing sugar released at the end of the reaction was determined by Dinitrosalisyilic Acid (DNS) method. Sample blank was used to correct for the non-enzymatic release of reducing sugar. One unit of pullulanse activity is defined as the amount of enzyme required to produce $1 \mu \mathrm{mol}$ reducing sugar (equivalent to glucose) $\min ^{-1}$ under the assay conditions.

Effect of pH on enzyme activity and stability: The $\mathrm{pH}$ optimum for the enzyme activity was studied over a range from $\mathrm{pH} 1-10$ with pullulan as a substrate. The $\mathrm{pH}$ stability of the enzyme was determined by incubating the enzyme in buffers with different $\mathrm{pHs}$ for $24 \mathrm{~h}$ and incubated at $40^{\circ} \mathrm{C}$. The following buffer systems were used: $0.02 \mathrm{M}$ potassium chloride- $\mathrm{HCl}$ buffer ( $\mathrm{pH} 1.0-\mathrm{pH} 2.0) ; 0.02 \mathrm{M}$ glycine- $\mathrm{HCl}$ buffer $(\mathrm{pH}$ 3); $0.02 \mathrm{M}$ acetate buffer (pH 4-pH 5); $0.02 \mathrm{M}$ phosphate buffer (pH 6-pH 8); and 0.02 M glycine$\mathrm{NaOH}$ buffer (pH 9-pH 10).

Thermal influence on enzyme activity: To determine the temperature optima on the enzyme activity, the reaction mixture was incubated at different temperatures for $30 \mathrm{~min}$ with and without the present of $\mathrm{Ca}^{2+}$ ion. Thermal stability was determined by incubating the enzyme sample in different buffers $(0.02$ $\mathrm{M}, \mathrm{pH}$ 6.9) with and without the present of $\mathrm{Ca}^{2+}$. The reaction mixtures were pre-incubated at various temperatures for $30 \mathrm{~min}$ and then residual pullulanase activities were assayed. 
Thermal inactivation was examined by incubating the enzyme at 50,60 and $70^{\circ} \mathrm{C}$ for $150 \mathrm{~min}$ with and without the present of $\mathrm{Ca}^{2+}$. Aliquots were withdrawn at desired time interval to test the remaining activity at standard conditions. The enzyme incubated at $4^{\circ} \mathrm{C}$ in the absence of an additive was used as a control and was assumed to have $100 \%$ activity.

Effect of metal ions, chemical reagents, carbohydrates and protein stabilizer salts on enzyme activity: The purified pullulanase was pretreated with various metal ions at two different concentrations $(0.2 \mathrm{mM}$ and $2 \mathrm{mM})$, various types of small carbohydrate (glycerol, mannitol, sorbitol, myoinositol, sucroce) and other protein stabilizer salts $\left(\mathrm{Na}_{2} \mathrm{SO}_{4}\right.$ and glycine). The reaction mixtures containing the enzyme sample and pullulan as a substrate were incubated at $55^{\circ} \mathrm{C}$ for $30 \mathrm{~min}$ in $0.02 \mathrm{M}$ sodium phosphate buffer, $\mathrm{pH}$ 6.9. The enzyme sample without any additives was considered as control (100\%).

Action of pullulanase on different concentrations of pullulan: The purified enzyme was also assayed for pullulanase activity at different concentrations of pullulan. Reaction rate (v) is expressed as $\mu$ mol of reducing sugar (as glucose) formed per $\mathrm{mg}$ of protein and substrate concentration (s) as $\mathrm{mg} \mathrm{mL}^{-1}$. The kinetic parameters, $\mathrm{K}_{\mathrm{m}}$ and $\mathrm{V}_{\max }$, were determined by EadieHofstee plot.

Substrate specificity: The ability of the purified enzyme to hydrolyze various carbohydrates was examined at $55^{\circ} \mathrm{C}$ and $\mathrm{pH} 6.9$ in $0.02 \mathrm{M}$ sodium phosphate buffer. The carbohydrates tested were pullulan, amylopectin (from potato), amylopectin (from maize), soluble starch (from potato), amylose, dextran and gelatinized sago starch at a concentration of $1 \%(\mathrm{w} / \mathrm{v})$.

End product analysis: The pullulanase sample $(10 \mathrm{~mL})$ was added into different substrates (pullulan, soluble starch and amylopectin) at a concentration of $1 \%$ $(\mathrm{w} / \mathrm{v})$ in $0.02 \mathrm{M}$ sodium phosphate buffer, at $\mathrm{pH}$ 6.9. The reaction mixtures were incubated at $55^{\circ} \mathrm{C}$. In order to determine the nature of the DP3 product of pullulan hydrolysis, Maltogenase ${ }^{\circledR} \mathrm{L}$, a maltogenic $\alpha$ amylase (from Bacillus stearothermophilus expressed in and produced by a genetically modified strain of Bacillus subtilis), product of Novozymes, was added to the reaction medium after $12 \mathrm{~h}$ of the action of pullulanase from B. cereus $\mathrm{H} 1.5$ on pullulan (at this time, the formation of DP3 product was maximum).
The Maltogenase ${ }^{\circledR} \mathrm{L}$ hydrolyzed $\quad \alpha$-1,4-glucosidic linkages in maltotriose and maltose units are removed in a stepwise manner from the non-reducing chain ends. The maltose released had the $\alpha$-configuration. As Maltogenase ${ }^{\circledR} \mathrm{L}$ is able to hydrolyze maltotriose, some D-glucose is formed.

During the reaction, samples were collected at time intervals for analysis using HPLC (Waters, USA). The Rezex RKP Potassium $(300 \times 7.8 \mathrm{~mm}$ ID) analytical column was used as a stationary phase while filtered distilled water was used as a mobile phase. The products were eluted with a mobile phase at a flow rate of $0.5 \mathrm{~mL} \mathrm{~min}{ }^{-1}$ and detected with a Refractive Index (RI) detector (Waters 996 Photodiode Array Detector). The column temperature was maintained at $80^{\circ} \mathrm{C}$ and the injection volume of each sample was $10 \mu \mathrm{L}$ and the running time was $15 \mathrm{~min}$. Standard sugar mixtures containing pure glucose, maltose, maltotriose, up to maltoheptaose (DP7) were used for the generation of calibration curves; DP denotes degree of polymerization.

\section{RESULTS}

Purification of pullulanase enzyme: Pullulanase produced by B. cereus $\mathrm{H} 1.5$ was purified 23.6-fold with a $8.5 \%$ yield and a final specific activity of $14.250 \mathrm{U} \mathrm{mg}^{-1}$ protein (Table 1). The homogeneity of the purified pullulanase was ascertained by SDS-PAGE. A single band of protein was obtained at approximately $93 \mathrm{kDa}$ (data not shown).

Effect of pH on the activity and stability of the enzyme: Effect of $\mathrm{pH}$ on the activity and stability of pullulanase from B. cereus H1.5 is shown in Fig. 1. The optimum $\mathrm{pH}$ for the activity of pullulanase was observed at $\mathrm{pH}$ 6.0. The pullulanase activity was apparent over the acidic ranges, with more than 50\% of the maximal activity was detected at $\mathrm{pH}$ ranging from 3-6. The enzyme activity was greatly reduced at $\mathrm{pH}$ of above 7. The enzyme was stable over a wide $\mathrm{pH}$ range, from 2-10.

Table 1: Protocols used to purify pullulanase from Bacillus cereus H1.5

\begin{tabular}{|c|c|c|c|c|c|}
\hline Step & $\begin{array}{l}\text { Total } \\
\text { activity } \\
\text { (Units) }\end{array}$ & $\begin{array}{l}\text { Total } \\
\text { protein } \\
(\mathrm{mg})\end{array}$ & $\begin{array}{l}\text { Specific } \\
\text { activity } \\
\left(\mathrm{U} \mathrm{mg}^{-1}\right)\end{array}$ & $\begin{array}{l}\text { Yield } \\
(\%)\end{array}$ & $\begin{array}{l}\text { Purification } \\
\text { (fold) }\end{array}$ \\
\hline Crude & 115.57 & 951.46 & 0.121 & 100 & 1.00 \\
\hline$\left(\mathrm{NH}_{4}\right)_{2} \mathrm{SO}_{4}$ fractionation & 20.46 & 14.63 & 1.399 & 17.7 & 11.5 \\
\hline DEAE sepharose & 6.74 & 0.75 & 8.987 & 10.9 & 18.4 \\
\hline Superdex 75 & 4.56 & 0.32 & 14.250 & 8.5 & 23.6 \\
\hline
\end{tabular}




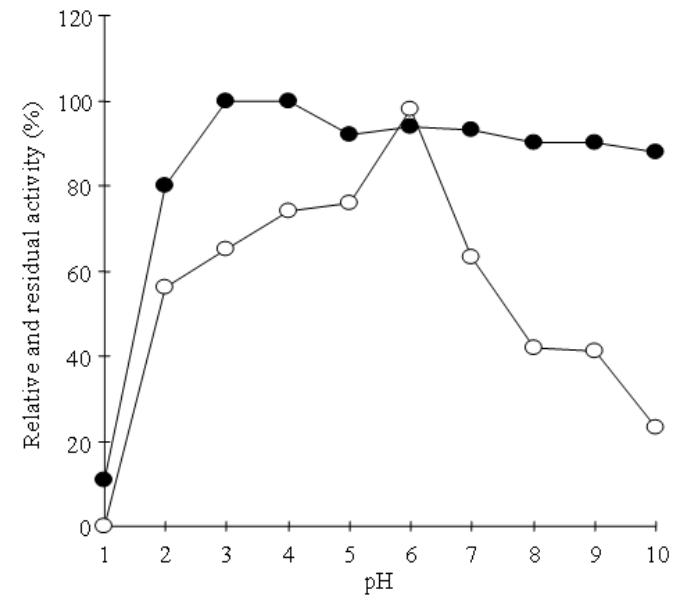

Fig. 1: Effect of $\mathrm{pH}$ on the activity and stability of pullulanase from Bacillus cereus H1.5. Symbols represent: (open circles) activity; (closed circles) stability

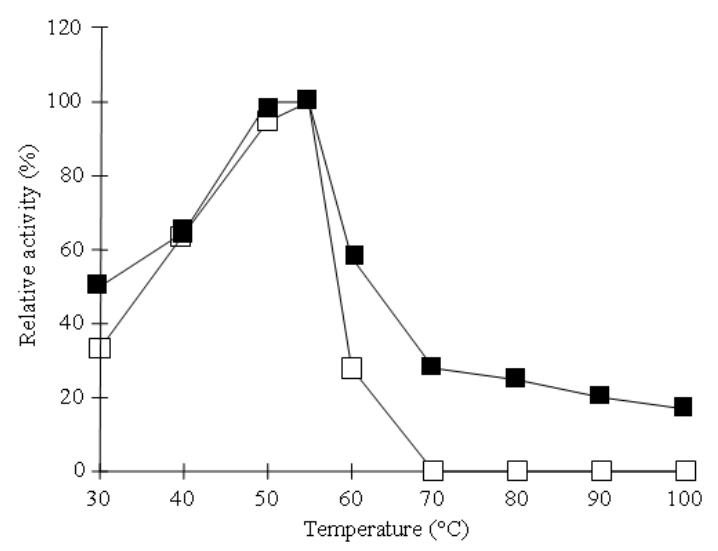

(A)

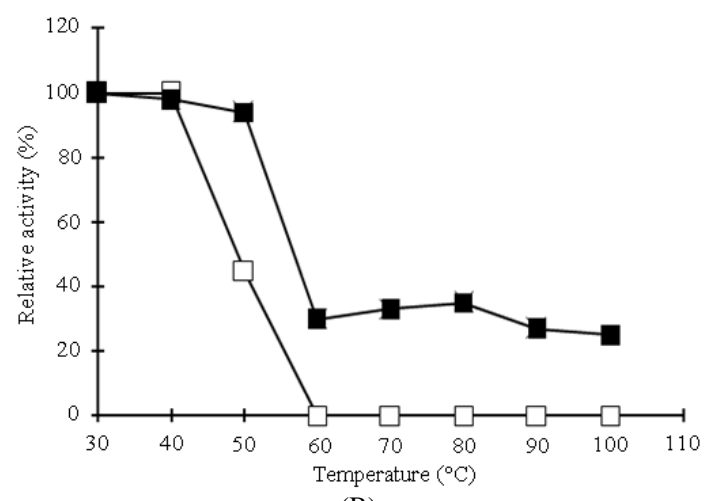

(B)

Fig. 2: Effect of temperature on activity (A) and stability (B) of pullulanase from Bacillus cereus H1.5. Symbols represent: (open squares) control; (closed squares) with $2 \mathrm{mM} \mathrm{Ca}^{2+}$
Effect of temperature on the activity and stability of the enzyme: The effect of temperature on the activity and stability of pullulanase from B. cereus $\mathrm{H} 1.5$ is shown in Fig. 2. The activity of pullulanase was optimal at $55^{\circ} \mathrm{C}$, for reaction with and without the present of $\mathrm{Ca}^{2+}$. For the enzyme without $\mathrm{Ca}^{2+}$, the activity was not detected at temperature of above $70^{\circ} \mathrm{C}$ (Fig. 2A). On the other hand, about $20 \%$ of relative activity was still maintained at temperature of above $70^{\circ} \mathrm{C}$ for pullulanase with $\mathrm{Ca}^{2+}$.

Fig. 2B shows that the enzyme was stable up to $40^{\circ} \mathrm{C}$, with essentially no loss of activity in $30 \mathrm{~min}$. The activity was decreased rapidly with increasing temperature of above $50^{\circ} \mathrm{C}$. Incubation for over $30 \mathrm{~min}$ at $60^{\circ} \mathrm{C}$ and above destroyed the activity completely. However, in the presence of $\mathrm{Ca}^{2+}$ the activity was stable up to $50^{\circ} \mathrm{C}$ and around $30 \%$ of its activity retained at temperature of above $60^{\circ} \mathrm{C}$.

Inactivation of pullulanase at two different temperatures, 50 and $60^{\circ} \mathrm{C}$, with and without the present of $\mathrm{Ca}^{2+}$ is shown in Fig. 3. The half life of pullulanase was more than $2 \mathrm{~h}$ for the enzyme with the present of $2 \mathrm{mM} \mathrm{Ca}^{2+}$ and incubated at $50^{\circ} \mathrm{C}$. At the same temperature, the half-life was reduced to $20 \mathrm{~min}$ for the enzyme without $2 \mathrm{mM} \mathrm{Ca}^{2+}$, suggesting that $\mathrm{Ca}^{2+}$ stabilized and protect the enzyme from thermal inactivation at $50^{\circ} \mathrm{C}$. However, the stabilization effect of $\mathrm{Ca}^{2+}$ on pullulanse from B. cereus $\mathrm{H} 1.5$ was not observed at higher temperature $\left(60^{\circ} \mathrm{C}\right)$.

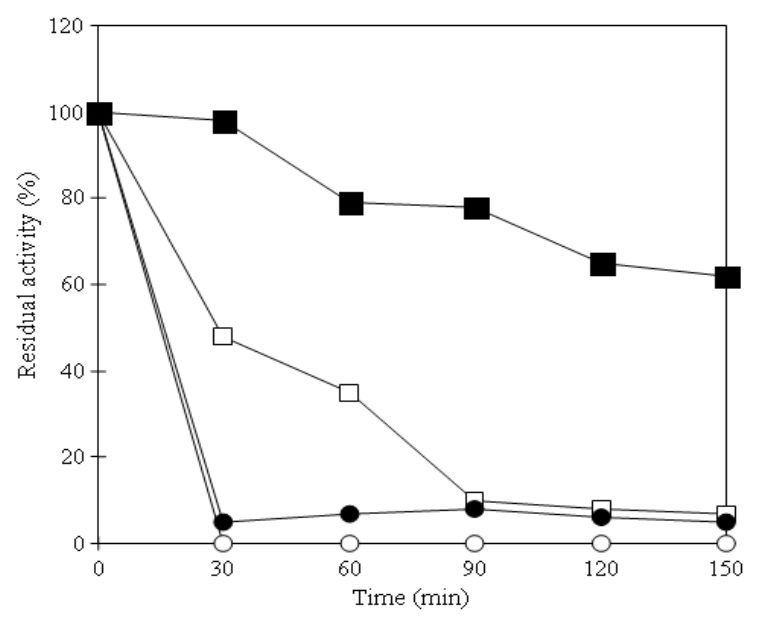

Fig. 3: Inactivation of pullulanase from Bacillus cereus H1.5 at different temperatures. Symbols represent: (open squares) control at $50^{\circ} \mathrm{C}$; (closed squares) with $2 \mathrm{mM} \mathrm{Ca}^{2+}$ at $50^{\circ} \mathrm{C}$; (open circles) control at $60^{\circ} \mathrm{C}$; (closed circles) 2 $\mathrm{mM} \mathrm{Ca}{ }^{2+}$ at $60^{\circ} \mathrm{C}$ 
Am. J. Biochem. \& Biotech., 5 (4): 170-179, 2009

Table 2: Comparison of metal ions as inhibitors for pullulanase from Bacillus cereus $\mathrm{H} 1.5$

\begin{tabular}{lcr}
\hline & Relative activity at two different concentrations \\
& $0.2 \mathrm{mM}$ & $2 \mathrm{mM}$ \\
\hline Reagents & 132.0 & 172.5 \\
$\mathrm{CaCl}_{2}$ & 5.2 & 4.8 \\
$\mathrm{NiCl}_{2}$ & 6.5 & 6.5 \\
$\mathrm{CoCl}_{2}$ & 18.9 & 5.8 \\
$\mathrm{CdCl} 2$ & 17.5 & 64.5 \\
$\mathrm{MnCl}_{2}$ & 18.4 & 65.8 \\
$\mathrm{MnSO}_{4}$ & 66.2 & 4.9 \\
$\mathrm{FeCl}_{3}$ & 8.5 & 6.4 \\
$\mathrm{MgCl}_{2}$ & 6.7 & 19.5 \\
$\mathrm{MgSO}_{4}$ & 3.8 & 0.5 \\
$\mathrm{CuSO}_{4}$ & 3.9 & 3.5 \\
$\mathrm{ZnCl}_{2}$ & 12.3 & 5.8 \\
$\mathrm{NaCl}_{\text {EDTA }}$ & 3.9 & 1.1 \\
$\mathrm{Control}$ & 100.0 & 100.0 \\
\hline
\end{tabular}

Effect of metal ions on enzyme activity: The inhibition effect of various metal ions on the activity of pullulanase from B. cereus $\mathrm{H} 1.5$ is shown in Table 2 . The pullulanase activity was inhibited strongly by $\mathrm{Ni}^{2+}$, $\mathrm{Co}^{2+}, \mathrm{Cd}^{2+}, \mathrm{Mg}^{2+}, \mathrm{Cu}^{2+}, \mathrm{Zn}^{2+}$ and $\mathrm{Na}^{+}$ions. The activity was slightly inhibited by $0.2 \mathrm{mM} \mathrm{Fe}{ }^{3+}$ ions but pullulanase activity was completely eliminated at higher concentration $(2 \mathrm{mM})$. In contrast to $\mathrm{Fe}^{3+}$, the activity of pullulanase was only slightly reduced at high concentration of $\mathrm{Mn}^{2+}$. Among the metal ions tested, $\mathrm{Ca}^{2+}$ had a very strong stimulating effect on the enzyme, increasing its activity by around $170 \%$.

Effect of various chemical reagents on enzyme activity: Effect of various chemical reagents on the activity of $B$. cereus $\mathrm{H} 1.5$ pullulanase is shown in Table 3. Strong inhibition on the pullulanase activity by $\mathrm{N}$ bromosuccinimide (NBS) was observed at low concentration, suggesting a crucial involvement of tryptophan residues at the active site of the enzyme.

The suphydryl inhibitors, such as 4chloromercuribenzoate, had no inhibitory effect on the pullulanase activity. The reducing agents, dithiothreitol and 2-mercaptoethanol, increased the pullulanase activity slightly, indicating the involvement of a thiolgroup in the catalytic action. The enzyme was not inhibited by phenylmethanesulphonyl fluoride (PMSF), suggesting that histidine and serine residues were not participate in the catalysis by the enzyme, as in general, amylolytic enzymes are not serine enzyme.

The enzyme activity was inhibited by the chelating agent (EDTA), with more than 92\% lost in activity. However, the pullulanase activity was slightly activated with $\mathrm{Ca}^{2+}$. This result indicates that $\mathrm{Ca}^{2+}$ is not required for its activity but is probably important for the stability and may maintain the conformation of the enzyme.
Table 3: Influence of various chemical reagents on the activity of pullulanase from Bacillus cereus $\mathrm{H} 1.5$

\begin{tabular}{llc}
\hline Chemical reagents & Concentration & $\begin{array}{l}\text { Relative } \\
\text { activity (\%) }\end{array}$ \\
\hline Control & - & 100 \\
Phenylmethysulfonyl fluoride & & \\
(PMSF) & $1 \mathrm{mM}$ & 95 \\
N-Bromosuccinimide & $0.1 \mathrm{mM}$ & 6 \\
& $0.3 \mathrm{mM}$ & 0 \\
4-chloromercuribenzoate & $0.1 \mathrm{mM}$ & 102 \\
EDTA & $10 \mathrm{mM}$ & 8 \\
EDTA $+\mathrm{Ca}^{2+}$ & $10+2 \mathrm{mM}$ & 21 \\
Urea & $0.1 \mathrm{M}$ & 109 \\
& $3 \mathrm{M}$ & 76 \\
& $7 \mathrm{M}$ & 29 \\
$\alpha$-cyclodextrin & $0.10 \%$ & 71 \\
& $0.50 \%$ & 25 \\
$\beta$-cyclodextrin & $0.10 \%$ & 21 \\
& $0.50 \%$ & 6 \\
$\gamma$-cyclodextrin & $0.10 \%$ & 53 \\
& $0.50 \%$ & 22 \\
Dithiothreitol & $2 \mathrm{mM}$ & 122 \\
2-mercaptoethanol & $2 \mathrm{mM}$ & 102
\end{tabular}

Table 4: Effect of polyols on thermostability of pullulanase from

\begin{tabular}{|c|c|}
\hline Polyols & Relative activity (\%) \\
\hline Control & 100.0 \\
\hline Glycerol & 58.1 \\
\hline Mannitol & 72.4 \\
\hline Sorbitol & 75.6 \\
\hline Myo-inositol & 158.8 \\
\hline $\mathrm{Na}_{2} \mathrm{SO}_{4}$ & 76.2 \\
\hline Glycine & 0.4 \\
\hline Sucrose & 172.6 \\
\hline
\end{tabular}

Effect of polyols on the enzyme activity: Thermostability of enzyme could also be enhanced by modification of the environment, such as with the addition of various polyols or simple sugar. Effect of polyols on the thermostability of pullulanase from B. cereus $\mathrm{H} 1.5$ is shown in Table 4 . Thermostability of pullulanase at $55^{\circ} \mathrm{C}$ was significantly improved with the addition of myo-inositol and sucrose into the reaction media. The highest improvement in stability (relative activity of $172.6 \%$ ) was obtained with sucrose. On the other hand, reduced thermostability of the enzyme was observed with the addition of other polyols. The enzyme was almost denatured with the present of glycine. The experiment was also conducted to investigate the effect of sucrose concentration (0.5-4 M) on pullulanase thermostability at $55^{\circ} \mathrm{C}$ (data not shown). The protective effect of sucrose on thermostability was optimal for sucrose concentration ranging from 1-2 M.

Kinetic properties of pullulanase activity: The activity of pullulanase from B. cereus $\mathrm{H} 1.5$ on pullulan as a substrate showed Michaelis-Menten kinetics, 
where the maximal activity was reached at pullulan concentration of $10 \mathrm{mg} \mathrm{mL}^{-1}$ (data not shown). The plot of Eadie-Hofstee for the determination of enzyme kinetics is shown in Fig. 4. The apparent MichaelisMenten constant $\left(\mathrm{K}_{\mathrm{m}}\right)$ value for pullulan was $1.1 \mathrm{mg}$ $\mathrm{mL}^{-1}$, while the value of $\mathrm{V}_{\max }$ was $0.275 \mu \mathrm{mol} \mathrm{min}{ }^{-1}$.

Substrate specificity and analysis of hydrolysis product by HPLC: A number of different $\alpha$-glucans were incubated with pullulanase from B. cereus $\mathrm{H} 1.5$ in order to ascertain the substrate specificity. Among the carbohydrate tested as substrate, the highest hydrolysis was observed with pullulan (Table 5). Amylopectin (potato) and soluble starch were hydrolysed to some extent, while amylose was cleaved at very low rate. The enzyme did not cleave dextran which containing only $\alpha-1,6$ glycosidic linkages.

Individual polysaccharides and oligosaccharides were incubated with pullulanase and the products were separated and identified by HPLC analysis. Figure 5 shows the time course of enzymatic hydrolysis of pullulan by $B$. cereus $\mathrm{H} 1.5$ pullulanase, while the end product profile is shown in Fig. 6.

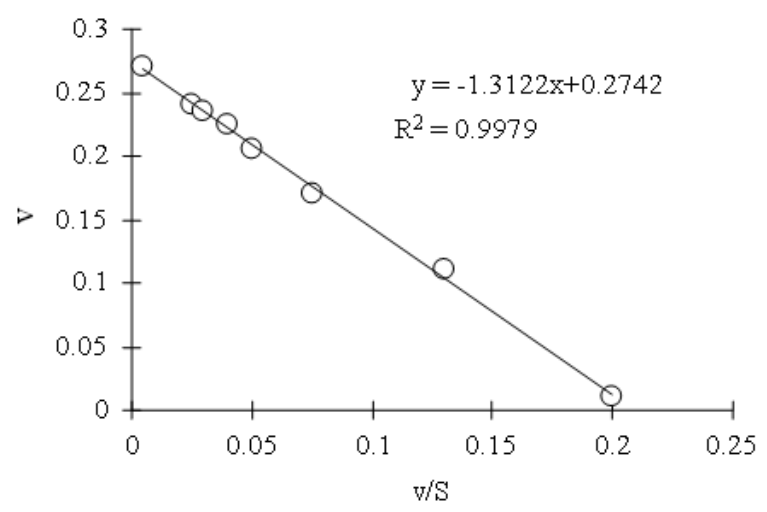

Fig. 4: Eadie-Hofstee plot for the determination of the kinetics of pullulanase from Bacillus cereus H1.5

Table 5: Substrate specificity of pullulanase from Bacillus cereus H1.5

\begin{tabular}{llr}
\hline Substrate $(1 \%, \mathrm{w} / \mathrm{v})$ & $\begin{array}{l}\text { Specific activity } \\
\left(\mathrm{U} \mathrm{mg}^{-1}\right)\end{array}$ & $\begin{array}{l}\text { Relative } \\
\text { activity }(\%)\end{array}$ \\
\hline Pullulan & 1.397 & 100.0 \\
Amylopectin (potato) & 0.398 & 28.5 \\
Amylopectin (maiza) & 0.076 & 5.5 \\
Amylose & 0.040 & 2.9 \\
Dextran & 0.003 & 0.2 \\
Soluble starch (potato) & 0.285 & 20.2 \\
Gelatinized sago & 0.013 & 1.0 \\
\hline
\end{tabular}

After $3 \mathrm{~h}$ incubation at $55^{\circ} \mathrm{C}$, the pullulan was converted into a major identifiable DP3 product. The final product after prolonged incubation (up to $13 \mathrm{~h}$ ) showed that DP3 was the only trimeric (degree of polymerization, DP) product of pullulan hydrolysis (Fig. 6B).

Furthermore, when this DP3 product was incubated with commercial Maltogenase ${ }^{\circledR} \mathrm{L}$ for $30 \mathrm{~min}$, it disappeared and led to form a DP2 (maltose) and glucose peaks (Fig. 6C). This result suggests that the DP3 product of pullulan hydrolysis had been a straight chain maltotriose with no $\alpha-(1,6)$ linkage and not panose or isopanose. In contrast, if the DP3 had been:

$$
\text { panose }(\alpha-D-G l c-[1 \rightarrow 6]-\alpha-D-G l c-[1 \rightarrow 4]-D-G l c)
$$

or

isopanose $(\alpha-\mathrm{D}-\mathrm{Glc}-[1 \rightarrow 4]-\alpha-\mathrm{D}-\mathrm{Glc}-[1 \rightarrow 6]-\mathrm{D}-\mathrm{Glc})$

the commercial enzyme could not have degraded it at all. Accordingly, the pullulanase attacks pullulan and release maltotriose, indicating that the enzyme had an absolute specificity directed at the $(1 \rightarrow 6)$ glucosidic linkages of pullulan.

Incubation of soluble starch, amylose and amylopectin with pullulanase for more than $24 \mathrm{~h}$ resulted in the formation of low level of maltose and glucose (data not shown) and the action of pullulanase on both soluble starch and amylopectin was very slow, demonstrating its low affinity for $\alpha$-1,4-glucosidic linkages. These results indicate that the enzyme acts on pullulan as a true pullulanase and has an endo-acting $\alpha$ amylase activity.

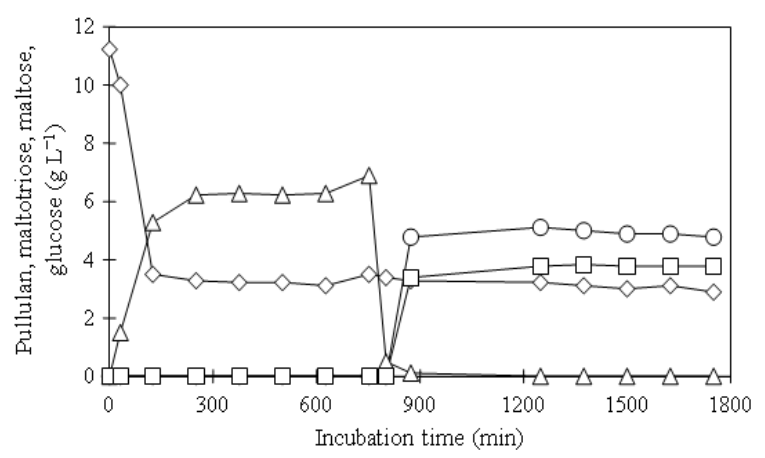

Fig. 5: Time course of enzymatic hydrolysis of pullulan by the pullulanase from Bacillus cereus H1.5. Symbols represent: (open diamonds) pullulan; (open triangles) maltotriose; (open circles) maltose; (open squares) glucose 


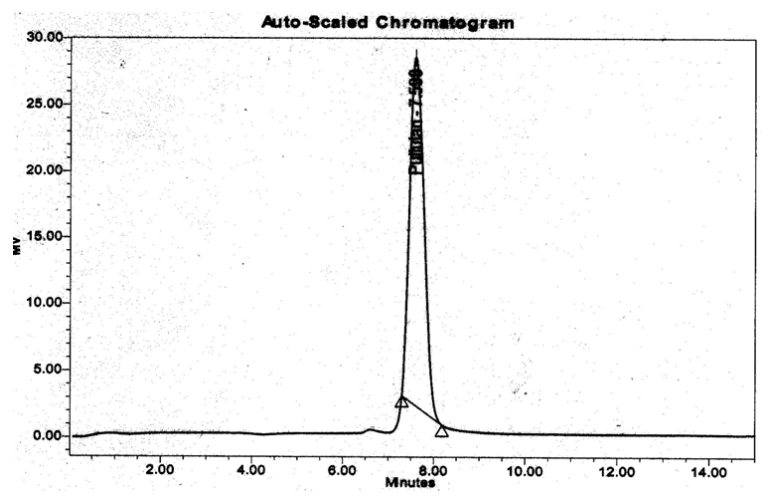

(A)

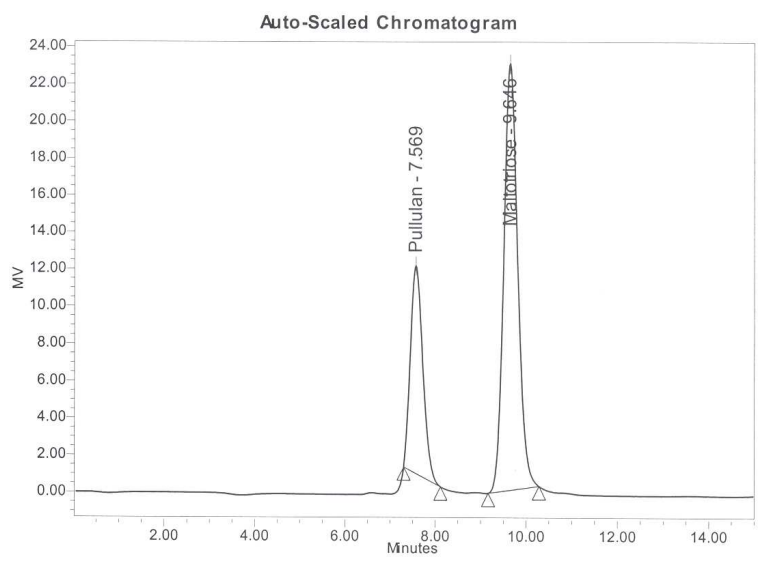

(B)

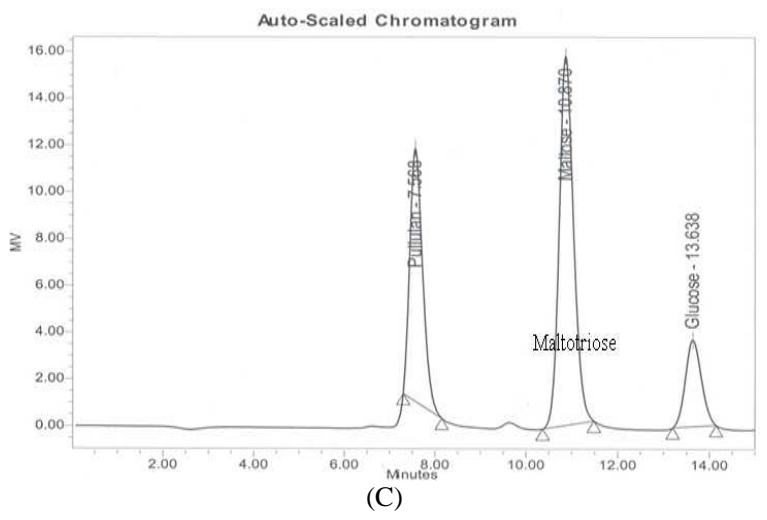

Fig. 6: End product profile of the action of pullulanase Bacillus cereus $\mathrm{H} 1.5$ on $1 \%$ pullulan as analyzed by HPLC. DP denotes degree of polymerization. (A) pullulan without enzyme as control; (B) after $3 \mathrm{~h}$ action on pullulan; (C) DP3 product degraded by Maltogenase ${ }^{\circledR} \mathrm{L}$

\section{DISCUSSION}

The optimal $\mathrm{pH}$ for pullulanase activity and the range of $\mathrm{pH}$ for pullulanase stability of observed in this study was in agreement with those reported for other sources of pullulanase $\mathrm{e}^{[3,4,14,18-19]}$. For example, the $\mathrm{pH}$ optima for most pullulanases were at $\mathrm{pH}$ of around 5.0 to 5.8. Likewise, pullulanase from other sources was also stable at $\mathrm{pH}$ ranging from 4-9 ${ }^{[4,21-23]}$, except for some alkaline pullulanases which were active and stable within the alkaline range of $\mathrm{pH}^{[23,24]}$.

The optimal temperature $\left(55^{\circ} \mathrm{C}\right)$ for activity of pullulanase from $B$. cereus $\mathrm{H} 1.5$ was comparable to pullulanase from other microbial sources, which were normally in the range from $40-60^{\circ} \mathrm{C}^{[3,23,25]}$, except for thermophilic bacterium and extreme thermophiles, which has optimal activity at temperature ranging from 70$100^{\circ} \mathrm{C}^{[3,4,18,20-22]}$. The thermostability of pullulanase from B. cereus $\mathrm{H} 1.5$ was increased from $40-50{ }^{\circ} \mathrm{C}$ in the present of $\mathrm{Ca}^{2+}$. Enhanced thermostability of pullulanase in the present of $\mathrm{Ca}^{2+}$ have been reported by many researchers. For example, pullulanase from $T$. litoralis and P. furiosus ${ }^{[14]}$, Bacillus stearothermophilus ${ }^{[26]}$ and Thermococcus hydrothermalis ${ }^{[18]}$. On the other hand, activity and stability of pullulanase from Desulfurococcus mucosus was not enhanced with the present of $\mathrm{Ca}^{2+[4]}$.

Indeed metal ions often act as salt or ion bridges between two adjacent amino acids ${ }^{[19]}$. This tryptophanspecific oxidant has been reported to inhibit the activity of pullulanase from strains of alkalophilic Bacillus sp. ${ }^{[23,24]}$, an anaerobic bacterium Desulfurococcus mucosus $^{[4]}$, Clostridium thermohydrosulfuricum ${ }^{[7]}$ and a hyperthermophilic archaeon Thermococcus hydrothermalis $^{[18]}$. It is well known that metal ions often act as salt or ion bridges between two adjacent amino acids ${ }^{[18]}$. Schardinger dextrins inhibited the pullulanase activity of $B$. cereus $\mathrm{H} 1.5$ and $\beta$-dextrin was a strongest inhibitor than $\alpha$ - and $\gamma$-dextrin. This is true with other pullulanases ${ }^{[7,19,25]}$, except pullulanase from an archaeal Desulfurococcus mucosus ${ }^{[4]}$ which was not inhibited by these possible competitive inhibitors of pullulanase.

From this study, it was found that the activity of pullulanase was quantitatively affected by the presence of small carbohydrates. Indeed, the catalytic efficiency of the enzymes depended on the additive present in the reaction medium and the influence was varied with its concentration. As a general rule, the catalytic efficiency increases with increasing sugar concentration to reach an optimum, after which it decreases. Addition of the highly soluble carbohydrates like polyols or simple sugars into enzymatic reaction media decreased the water activity, which in turn, the physicochemical properties will also be modified. These additives were also found relevant in regards to the thermal stability of the enzymes ${ }^{[27]}$. In addition, these protective effects 
were explained by the strengthening of the hydrophobic interactions inside protein molecules and by indirect action of additives on water structure ${ }^{[28]}$. Furthermore, increased in the thermal stability of proteins may be due to increasing in rigidity of their tertiary structure ${ }^{[29]}$.

The pullulanase of $B$. cereus $\mathrm{H} 1.5$ did not cleave dextran which containing only $\alpha-1,6$ glycosidic linkages, as observed for many pullulanases ${ }^{[4,21]}$. Since pullulanase from $B$. cereus $\mathrm{H} 1.5$ attacks pullulan (producing maltotriose) and other polysaccharides such as starch and amylopectin, it can be classified as a pullulanase type II or amylopullulanase. The molecular mass of pullulanase produced by $B$. cereus H1.5 was bigger than pullulanase produced by $A$. niger $(69 \mathrm{kDA})^{[17]}$ and almost similar to pullulanase produced by Bacillus sp. US149 (95 KDA) ${ }^{[3]}$. This enzyme has ability to hydrolyse pullulan to produce maltotriose as a final product. The enzyme was able to attack specifically the $\alpha-1,6$ linkages in pullulan to generate maltotriose as the major end product, as well as the $\alpha$ 1,4 linkages in amylopectin and soluble starch. The enzyme also exhibits some distinct features in term of thermoactivity and thermostability as well as well as stability at wide range of $\mathrm{pH}$ (2-10). Pullulanase type II is normally produced by the extreme thermophilic bacteria where the cultivation is difficult. In this case, the producing microorganism (B. cereus) can be grown easily, thus the enzyme production process may have potential to be transferred directly into industrial applications without the need in the development of recombinant strains.

\section{CONCLUSION}

Pullulanase type II, produced by $B$. cereus $\mathrm{H} 1.5$, was capable to attack specifically the $\alpha-1,6$ linkages in pullulan to generate maltotriose as the major end product, as well as the $\alpha-1,4$ linkages in amylopectin and soluble starch leading to the formation of a mixture of maltose and glucose. A relative substrate specificity for hydrolysis of pullulan, amylopectin and soluble starch by this pullulanase was 100, 28.5 and $20.4 \%$, respectively. The reaction of this pullulanase on pullulan has apparent $\mathrm{K}_{\mathrm{m}}$ and $\mathrm{V}_{\max }$ value of $1.1 \mathrm{mg} \mathrm{mL}^{-1}$ and $0.275 \mu \mathrm{mol} \mathrm{min}^{-1}$, respectively. This pullulanase showed optimal activity at $55^{\circ} \mathrm{C}$ and $\mathrm{pH} 6.0$ and its thermostability and thermoactivity were increased considerably in the presence of $\mathrm{Ca}^{2+}$. The enzyme was activated by 2 -mercaptoethanol and dithiothreitol and deactivated N-bromosuccinimide and Schardinger dextrins.

\section{REFERENCES}

1. Haki, G.D. and S.K. Rakshit, 2003. Developments in industrially important thermostable enzymes: A review. Bioresour. Technol., 89:17-34. DOI: 10.1016/S0960-8524(03)00033-6

2. Bertoldo, C. and G. Antranikian, 2002. Starchhydrolyzing enzymes from thermophilic archaea and bacteria. Curr. Opin. Chem. Biol., 6: 151-160. DOI: 10.1016/S1367-5931(02)00311-3

3. Roy, A., E.B. Messaoud and S. Bejar, 2003. Isolation and purification of an acidic pullulanase type II from newly isolated Bacillus sp. US149. Enz. Microb. Technol., 33:720-724. DOI: 10.1016/S0141-0229(03)00212-6.

4. Duffner, F., C. Bertoldo, J. T. Andersen, K. Wagner and G. Antranikian, 2000. A new thermoactive pullulanase from Desulfurococcus mucosus: Cloning, sequencing, purification and characterization of the recombinant enzyme after expression in Bacillus subtilis. J. Bacteriol., 182: 6331-6338.

http://jb.asm.org/cgi/content/abstract/182/22/6331

5. Takasaki, Y., 1987. Pullulanase-amylase complex enzyme from Bacillus subtilis. Agric. Biol. Chem., 51: $9-16$.

http://www.journalarchive.jst.go.jp/jnlpdf.php?cdjo urnal=bbb1961\&cdvol=51\&noissue $=1 \&$ startpage $=$ 9\&lang=en\&from=jnlabstract

6. Coleman, R.D., S.S. Yang and M.P. McAlister, 1987. Cloning of the debranching-enzyme gene from Thermoanaerobium brockii into Escherichia coli and Bacillus subtilis. J. Bacteriol., 169: 4302-4307.

http://jb.asm.org/cgi/reprint/169/9/4302?maxtosho $\mathrm{w}=\&$ HITS $=10 \&$ hits $=10 \&$ RESULTFORMAT $=\& \mathrm{fu}$ lltext=Cloning + of + the + debranching-

enzyme+gene+from+Thermoanaerobium+brockii+ into\&searchid $=1 \&$ FIRSTINDEX $=0 \&$ resourcetype $=$ HWCIT

7. Saha, B.C., S.P. Mathupala and J.G. Zeikus, 1988. Purification and characterization of a highly thermostable novel pullulanase from Clostridium thermohydrosulfuricum. Biochem. J., 252: 343-348.

http://www.pubmedcentral.nih.gov/picrender.fcgi? artid $=1149150 \&$ blobtype $=$ pdf

8. Melasniemi, H., 1988. Purification and some properties of the extracellular alpha-amylase-pullulanase produced by Clostridium thermohydrosulfuricum. Biochem. $\quad$ J., 250: 813-818. http://www.pubmedcentral.nih.gov/picrender.fcgi? artid $=1148928 \&$ blobtype $=$ pdf 
9. Sata, H., M. Umeda, C.H. Kim, H. Taniguchi and Y. Maruyama, 1989. Amylase-pullulanase enzyme produced by $B$. circulans F-2. Biochim. Biophys. Acta, 991: 388-394. DOI: 10.1016/03044165(89)90062-7

10. Saha, B.C., G.J. Shen, K.C. Srivastava, L.W. LeCureux and J.G. Zeikus, 1989. New thermostable $\alpha$ amylase-like pullulanase from thermophilic Bacillus sp. 3183. Enz. Microb. Technol., 11: 760-764. DOI: 10.1016/0141-0229(89)90126-9

11. Spreinat, A. and G. Antranikian, 1990. Purification and properties of a thermostable pullulanase from Clostridium thermosulfurogens EM1 which hydrolyses both $\alpha-1,6$ and $\alpha-1,4$-glycosidic linkages. Applied Microbiol. Biotechnol., 33: 511-518. DOI: 10.1007/BF00172543.

12. Plant, A.R., H.W. Morgan and R.M. Daniel, 1986. A highly stable pullulanase from Thermus aquaticus YT-1. Enzyme Microb. Technol., 8: 668-672. DOI: 10.1016/0141-0229(86)90063-3

13. Saha, B.C., R. Lamed, C.Y. Lee, S.P. Mathupala and J.G. Zeikus, 1990. Characterization of an endoacting amylopullulanase from Thermoanaerobacter strain B6A. Applied Environ. Microbiol., 56: 881-886. http://aem.asm.org/cgi/reprint/56/4/881?maxtosho $\mathrm{w}=\&$ HITS $=10 \&$ hits $=10 \&$ RESULTFORMAT $=\& \mathrm{fu}$ lltext=Characterization+of + an+endoacting+amylopullulanase+from+Thermoanaerobact er+strain\&searchid $=1 \&$ FIRSTINDEX $=0 \&$ resource type $=$ HWCIT

14. Brown, S.H. and R.M. Kelly, 1993. Characterization of amylolytic enzymes, having both $\alpha-1,4$ and $\alpha-1,6$ hydrolytic activity, from the thermophilic archaea Pyrococcus furiosus and Thermococcus litoralis. Applied Environ. Microbiol. 59: 2614-2621. http://aem.asm.org/cgi/reprint/59/8/2614?maxtosho $\mathrm{w}=\&$ HITS $=10 \& \mathrm{hits}=10 \&$ RESULTFORMAT $=\& \mathrm{fu}$ lltext=Characterization + of + amylolytic+enzymes $+\mathrm{h}$ aving+both $+\%$ EF\% $81 \% \mathrm{~A} 1-$

$1 \% 2 \mathrm{C} 4+$ and $+\% \mathrm{EF} \% 81 \% \mathrm{~A} 1-$

$1 \% 2 \mathrm{C} 6+$ hydrolytic+activity+from+the+thermophil ic $+\&$ searchid $=1 \&$ FIRSTINDEX $=0 \&$ resourcetype $=$ HWCIT

15. Lin, L.L., M.R. Tsau and W.S. Chu, 1994. General characteristics of thermostable amylopullulanases and amylases from the alkalophilic Bacillus sp. TS23. Applied Microbiol. Biotechnol., 42: 51-56. DOI: $10.1007 / \mathrm{BF} 00170224$

16. Ling, H.S., 2006. Production of pullulanase by Raoultella planticola DSMZ using sago starch as carbon source. Ph.D. Thesis, University Putra Malaysia, Selangor, Malaysia.
17. Miller, G.L., 1959. Use of dinitrosalicylic acid reagent for determination of reducing sugar. Anal. Chem., 31: 426-428. DOI: 10.1021/ac60147a030

18. Aoki, H., Yopi, A. Padmajanti and Y. Sakano, 1996. Two components of cell-bound isopullulanase from Aspergillus niger ATCC 9642-Their purification and enzymatic properties. Biosci. Biotechnol. Biochem., 60: 1795-1798. PMID: 8987855

19. Gantelet, H. and F. Duchiron, 1998. Purification and properties of a thermoactive and thermostable pullulanase from Thermococcus hydrothermalis, a hyperthermophilic archaeon isolated from a deepsea hydrothermal vent. Applied Microbiol. Biotechnol., 49: 770-777. DOI: 10.1007/s002530051245

20. Bertoldo, C., F. Duffner, P.L. Jorgensen and G. Antranikian, 1999. Pullulanase type I from Fervidobacterium pennavorans Ven5: Cloning, sequencing and expression of the gene and biochemical characterization of the recombinant enzyme. Applied Environ. Microbiol., 65: 2084-2091. http://aem.asm.org/cgi/reprint/65/5/2084

21. Hyun, H.H. and J.G. Zeikus, 1985. General biochemical characterization of thermostable pullulanase and glucoamylase from Clostridium thermohydrosulfuricum. Applied Environ. Microbiol., 49: 1168-1173. http://aem.asm.org/cgi/reprint/49/5/1168?maxtosho $\mathrm{w}=\&$ HITS $=10 \&$ hits $=10 \&$ RESULTFORMAT $=\& \mathrm{fu}$ lltext $=$ General+biochemical+characterization $+\mathrm{of}+\mathrm{t}$ hermostable+pullulanase+and+glucoamylase+from + Clostridium+thermohydrosulfuricum\&searchid $=1$ \&FIRSTINDEX $=0$ \&resourcetype $=$ HWCIT

22. Kim, C.H., O. Nashiru and J.H. Ko, 1996. Purification and biochemical characterization of pullulanase type I from Thermus caldophilus GK24. FEMS Microbiol. Lett., 138: 147-152. DOI: 10.1111/j.1574-6968.1996.tb08148.x

23. Gomes, I., J. Gomes and W. Steiner, 2003. Highly thermostable amylase and pullulanase of the extreme thermophilic eubacterium Rhodothermus marinus: Production and partial characterization. Bioresour. Technol., 90: 207-214. DOI: 10.1016/S09608524(03)00110-X

24. Ara, K., K. Igarashi, K. Saeki, S. Kawai and S. Ito, 1992. Purification and some properties of an alkaline pullulanase from alkalophilic Bacillus sp. KSM-1876. Biosci. Biotechnol. Biochem., 56: 62-65. http://nels.nii.ac.jp/els/110002691615.pdf?id=ART 0002967011\&type $=$ pdf\&lang $=$ en \&host $=$ cinii\&ord er_no $=\& p p v \_t y p e=0 \& l a n g \_s w=\& n o=1253595189$ $\& \mathrm{cp}=$ 
25. Ara, K., K. Saeki, K. Igarashi, M. Takaiwa, T. Uemura, H. Hagihara, S. Kawai and S. Ito, 1995. Purification and characterization of an alkaline amylopullulanase with both $\alpha-1,4$ and $\alpha-1,6$ hydrolytic activity from alkalophilic Bacillus sp. KSM-1378. Biochim. Biophys. Acta, 1243: 315-324. DOI: 10.1016/0304-4165(94)00148-Q

26. Stefanova, M. E., R. Schwerdtfeger, G. Antranikian and R. Scandurra, 1999. Heat-stable pullulanase from Bacillus acidopullulyticus: Characterization and refolding after guanidinium chloride-induced unfolding. Extremophiles, 3:147-152. DOI: 10.1007/s007920050110

27. Kuriki, T., J.H. Park and T. Imanaka, 1990. Characteristics of thermostable pullulanase from Bacillus stearothermophilus and the Nucleotide sequence of the gene. J. Ferment. Bioeng., 69: 204-210. DOI: 10.1016/0922338X(90)90213-G
28. Mejri, M. and M. Mathlouthi, 2001. Effect of small carbohydrates on the catalytic activity of a protease and two glycohydrolases. Carbohydr. Polym., 45: 161-167. DOI: 10.1016/S01448617(00)00316-7

29. Ghorbel, B., A. Sellami-Kamoun and M. Nasri, 2003. Stability studies of protease from Bacillus cereus BG1. Enz. Microb. Technol., 32: 513-518. DOI: 10.1016/S0141-0229(03)00004-8

30. Germain, P., T. Slagmolen and R.R. Crichton, 1989. Relation between stabilization and rigidification of the three-dimensional structure of an enzyme. Biotechnol. Bioeng., 33: 563-569. DOI: 10.1002/bit.260330508 